\title{
Feedforward and Feedback Motor Control Abnormalities Implicate Cerebellar Dysfunctions in Autism Spectrum Disorder
}

\author{
DMatthew W. Mosconi, ${ }^{1}$ Suman Mohanty, ${ }^{1}$ Rachel K. Greene, ${ }^{1}$ Edwin H. Cook, ${ }^{2}$ David E. Vaillancourt, ${ }^{3}$ \\ and John A. Sweeney ${ }^{1,4}$ \\ ${ }^{1}$ Center for Autism and Developmental Disabilities, University of Texas Southwestern, Dallas, Texas 75235-9086, ${ }^{2}$ Institute of Juvenile Research, University \\ of Illinois at Chicago, Chicago, Illinois 60608, ${ }^{3}$ Department of Applied Physiology and Kinesiology, University of Florida, Gainesville, Florida 32611-8205, \\ and ${ }^{4}$ Center for Autism Spectrum Disorders, Bond University, Robina, Queensland 4226, Australia
}

\begin{abstract}
Sensorimotor abnormalities are common in autism spectrum disorder (ASD) and among the earliest manifestations of the disorder. They have been studied far less than the social-communication and cognitive deficits that define ASD, but a mechanistic understanding of sensorimotor abnormalities in ASD may provide key insights into the neural underpinnings of the disorder. In this human study, we examined rapid, precision grip force contractions to determine whether feedforward mechanisms supporting initial motor output before sensory feedback can be processed are disrupted in ASD. Sustained force contractions also were examined to determine whether reactive adjustments to ongoing motor behavior based on visual feedback are altered. Sustained force was studied across multiple force levels and visual gains to assess motor and visuomotor mechanisms, respectively. Primary force contractions of individuals with ASD showed greater peak rate of force increases and large transient overshoots. Individuals with ASD also showed increased sustained force variability that scaled with force level and was more severe when visual gain was highly amplified or highly degraded. When sustaining a constant force level, their reactive adjustments were more periodic than controls, and they showed increased reliance on slower feedback mechanisms. Feedforward and feedback mechanism alterations each were associated with more severe social-communication impairments in ASD. These findings implicate anterior cerebellar circuits involved in feedforward motor control and posterior cerebellar circuits involved in transforming visual feedback into precise motor adjustments in ASD.
\end{abstract}

Key words: autism spectrum disorder; cerebellum; precision grip; sensorimotor

\section{Introduction}

Sensorimotor abnormalities are nearly ubiquitous in autism spectrum disorder (ASD; Green et al., 2002; De Jong et al., 2011). They also are perhaps the earliest emerging features (Teitelbaum et al., 1998, 2003; Landa and Garrett-Mayer, 2006; Bryson et al., 2007; Landa et al., 2013; Elberling et al., 2014), and they appear to be familial (Mosconi et al., 2010). Pathology of cortico-cerebellar networks involved in sensorimotor control has been documented repeatedly in ASD, although the specific circuits that are affected remain unclear (Amaral et al., 2008; Stanfield et al., 2008; Stoodley, 2014). Thus, sensorimotor impairments are important targets for

Received July 4, 2014; revised Nov. 12, 2014; accepted Dec. 15, 2014.

Author contributions: M.W.M., D.E.V., and J.A.S. designed research; M.W.M., S.M., E.H.C., D.E.V., and J.A.S. performed research; M.W.M., S.M., and R.K.G. analyzed data; M.W.M., E.H.C., D.E.V., and J.A.S. wrote the paper.

This study was supported by National Institute of Mental Health Grant 092696, National Institute of Child Health and Human Development Autism Center of Excellence Award HD055751, Autism Speaks, and National Institutes of Health Grant R01 NS058487.

D.E.V. consults for projects at the University of Texas Southwestern Medical Center, University of Illinois at Chicago, and Great Lakes NeuroTechnologies. He is cofounder of Neuroimaging Solutions. J.A.S. served on advisory boards for Roche, Takeda, BMS, and Lilly.

Correspondence should be addressed to Dr. Matthew W. Mosconi, 5323 Harry Hines Boulevard, Dallas, TX753909086. E-mail:matt.mosconi@utsouthwestern.edu.

DOI:10.1523/JNEUROSCI.2731-14.2015

Copyright $\odot 2015$ the authors $\quad 0270-6474 / 15 / 352015-11 \$ 15.00 / 0$
ASD research aimed at facilitating earlier detection, identifying familial mechanisms, and characterizing neural system alterations that contribute to the disorder.

Sensorimotor behavior is the product of interacting feedforward and sensory feedback processes. Feedforward control is guided by internal action representations that plan initial motor output before the time when sensory feedback can be translated into corrective adjustments (Ghez et al., 1991). These action representations are believed to be generated in anterior cerebellar lobules I-V (Desmurget and Grafton, 2000; Molinari et al., 2002; Daskalakis et al., 2004).

Some studies have reported that feedforward mechanisms are intact in ASD (Minshew et al., 1999; Gowen and Miall, 2005), whereas others have identified reduced precision of initial motor output (Takarae et al., 2004; Glazebrook et al., 2006; Schmitt et al., 2014). Control of initial grasping behavior appears to be disrupted in ASD as demonstrated by an increased duration between the onset of lifting and gripping forces (David et al., 2009, 2012). This delay could reflect reduced coordination of proximal (shoulder/arm muscles used for lifting the arm) and distal (hand/finger muscles used to grasp the object) components or failures in feedforward mechanisms used to predictively control initial motor output. The mechanisms contributing to reduced control of initial motor output remain unclear. 
Table 1. Demographic characteristics of participants with ASD and healthy controls

\begin{tabular}{|c|c|c|c|c|c|c|c|c|}
\hline \multirow[b]{2}{*}{ Subject } & \multicolumn{2}{|c|}{ Age (years) } & \multicolumn{2}{|c|}{ Gender } & \multicolumn{2}{|c|}{ Nonverbal IQ } & \multicolumn{2}{|c|}{ Handedness } \\
\hline & ASD & Control & ASD & Control & ASD & Control & ASD & Control \\
\hline 1 & 5 & 5 & $M$ & $M$ & 102 & 107 & $\mathrm{R}$ & $\mathrm{R}$ \\
\hline 2 & 7 & 6 & $M$ & M & 81 & 104 & $R$ & $R$ \\
\hline 3 & 8 & 7 & $M$ & $\mathrm{~F}$ & 106 & 103 & $R$ & $\mathrm{~L}$ \\
\hline 4 & 8 & 7 & $M$ & M & 99 & 97 & $R$ & $\mathrm{R}$ \\
\hline 5 & 8 & 8 & $M$ & M & 91 & 99 & $R$ & $\mathrm{R}$ \\
\hline 6 & 9 & 9 & $M$ & $\mathrm{~F}$ & 90 & 113 & $R$ & $R$ \\
\hline 7 & 9 & 10 & $\mathrm{~F}$ & M & 71 & 100 & $\mathrm{R}$ & $\mathrm{R}$ \\
\hline 8 & 10 & 10 & $M$ & M & 88 & 124 & $\mathrm{R}$ & $R$ \\
\hline 9 & 10 & 11 & $M$ & M & 112 & 84 & $\mathrm{R}$ & $R$ \\
\hline 10 & 11 & 12 & $M$ & M & 119 & 100 & R & $R$ \\
\hline 11 & 11 & 12 & $M$ & $\mathrm{~F}$ & 117 & 115 & $\mathrm{R}$ & $R$ \\
\hline 12 & 12 & 12 & $M$ & M & 110 & 98 & $\mathrm{R}$ & $\mathrm{R}$ \\
\hline 13 & 12 & 13 & $M$ & M & 100 & 119 & $\mathrm{R}$ & $\mathrm{R}$ \\
\hline 14 & 12 & 13 & $M$ & M & 84 & 105 & L & $R$ \\
\hline 15 & 12 & 14 & $M$ & M & 146 & 103 & $\mathrm{R}$ & $\mathrm{R}$ \\
\hline 16 & 15 & 14 & $\mathrm{~F}$ & M & 94 & 99 & $\mathrm{R}$ & $R$ \\
\hline 17 & 15 & 15 & $\mathrm{~F}$ & M & 86 & 107 & $\mathrm{R}$ & $R$ \\
\hline 18 & 15 & 16 & $M$ & M & 89 & 107 & R & $R$ \\
\hline 19 & 17 & 16 & $\mathrm{~F}$ & M & 81 & 104 & $\mathrm{R}$ & $R$ \\
\hline 20 & 18 & 16 & $M$ & $\mathrm{~F}$ & 119 & 100 & $\mathrm{R}$ & $\mathrm{R}$ \\
\hline 21 & 19 & 16 & $M$ & M & 77 & 79 & $\mathrm{R}$ & $\mathrm{R}$ \\
\hline 22 & 21 & 17 & $M$ & M & 126 & 101 & $\mathrm{R}$ & $\mathrm{R}$ \\
\hline 23 & 23 & 20 & $M$ & M & 87 & 99 & $\mathrm{R}$ & $\mathrm{R}$ \\
\hline 24 & 23 & 21 & M & M & 59 & 111 & $\mathrm{R}$ & $\mathrm{R}$ \\
\hline 25 & 25 & 22 & $\mathrm{~F}$ & M & 124 & 123 & L & R \\
\hline 26 & 26 & 24 & $M$ & M & 98 & 116 & $R$ & $\mathrm{R}$ \\
\hline 27 & 34 & 28 & $M$ & $F$ & 100 & 104 & $\mathrm{R}$ & $\mathrm{R}$ \\
\hline 28 & 35 & 28 & M & M & 123 & 109 & L & $\mathrm{R}$ \\
\hline 29 & & 32 & & M & & 103 & & $\mathrm{R}$ \\
\hline Mean $\pm S D$ & $15 \pm 8$ & $15 \pm 7$ & $23 \mathrm{M}$ & $24 \mathrm{M}$ & $99 \pm 19$ & $105 \pm 10$ & $25 R$ & $28 R$ \\
\hline
\end{tabular}

Full-scale and verbal IQ scores were significantly higher $(p<0.01)$ in the control compared with the ASD groups (full-scale IQ: ASD, $99 \pm 19$ vs controls, $111 \pm 12$; verbal IQ: ASD, $100 \pm 22$ vs controls, $114 \pm 16$ ). F, Female; M, male; L, left; R, right.

Feedback control involves transforming sensory information into new motor commands to adjust ongoing motor behavior (Desmurget and Grafton, 2000; Slifkin et al., 2000; Sosnoff and Newell, 2005). During visuomotor behavior, visual information encoded in striate cortices is transferred to posterior parietal cortices and then posterior cerebellum (Stein, 1986; Kawato et al., 1987; Chen-Harris et al., 2008). The cerebellum transforms visual inputs into corrective motor commands that reduce the variability and imprecision of motor output (Vaillancourt et al., 2003, 2006b).

Sustained movements, or those that require a constant level of motor output, are reduced in accuracy and show atypical kinematic profiles in ASD (Takarae et al., 2004; Glazebrook et al., 2006, 2009; Cook et al., 2013; Torres et al., 2013). The extent to which these deficits reflect failures in processing sensory feedback or in adjusting motor output is not known.

Here, we examined rapid and sustained force contractions in ASD to assess feedforward and feedback control mechanisms, respectively. We predicted reduced accuracy of rapid contractions and increased sustained force variability in ASD. It was expected that increases in force variability in ASD would scale with force level and visual gain, implicating deficits in both motor and visuomotor processes.

\section{Materials and Methods}

\section{Participants}

Twenty-eight participants with ASD (23 males and 5 females) and 29 healthy controls (24 males and 5 females) matched on age (range, 5-35 years), nonverbal IQ, handedness, and gender performed tests of precision grip force separately for each hand (Table 1). IQ testing for individ- uals older than age 18 years was performed using the Wechsler Abbreviated Scale of Intelligence (Wechsler, 2011; $n=9$ individuals with ASD, 7 controls); individuals younger than age 18 years completed the Differential Ability Scales-II (Elliott, 2007; $n=19$ individuals with ASD, 22 controls).

Individuals with a Diagnostic and Statistical Manual of Mental Disorders, Edition 5 ASD diagnosis (American Psychiatric Association, 2013) were recruited through community advertisements. Diagnoses of ASD were confirmed using the Autism Diagnostic Inventory-Revised (ADI; Lord et al., 1994), the Autism Diagnostic Observation Schedule (ADOS; Lord et al., 2000), and expert clinical opinion. Participants with ASD were excluded if they had a known genetic or metabolic disorder associated with ASD (e.g., fragile X syndrome). Control participants were recruited from the community. All had a score $\leq 8$ on the Social Communication Questionnaire (Rutter et al., 2003) and no known history of psychiatric or neurological disorders, family history of ASD in first-, second-, or third-degree relatives, or a history in first-degree relatives of a developmental or learning disorder, psychosis, or obsessive compulsive disorder. No participants were taking medications known to affect sensorimotor control at the time of testing, including antipsychotics, stimulants, or anticonvulsants (Reilly et al., 2008). Five participants with ASD were taking Lexapro at the time of testing. Participants had corrected or uncorrected far visual acuity of at least 20/40. No participant had a history of head injury, birth injury, or seizure disorder. After a complete description of the study, written informed consent was obtained according to the Declaration of Helsinki for each adult participant, and informed parental consent was obtained for individuals aged $<18$ years. Minors provided written assent. Study procedures were approved by the local institutional review board.

\section{Experimental design}

Stimuli were presented on a $102 \mathrm{~cm}$ (40 inches) Samsung LCD monitor with a resolution of $1366 \times 768$ and a $120 \mathrm{~Hz}$ refresh rate. Participants were tested in a darkened black room and seated $52 \mathrm{~cm}$ from the display monitor. They sat with their elbow at $90^{\circ}$ and their forearm resting in a relaxed position on a custom-made arm brace (Fig. $1 A$ ). The arm brace was clamped to a table to keep the participant's arm position stable throughout testing. The participant's hand was pronated and lay flat with the digits comfortably extended. Participants used their thumb and index finger to press against two opposing precision load cells (ELFF-B4-100N; Entran) $1.27 \mathrm{~cm}$ in diameter secured to a custom grip device attached to the arm brace (Fig. 1B). Analog output from the load cells was amplified by a Grass Neurodata 12 Acquisition System (Astro-Med) at an excitation voltage of $10 \mathrm{~V}$ and a gain of 100 . Data were sampled at $200 \mathrm{~Hz}$ with a 12 bit analog-to-digital converter (DI-720; Dataq Instruments). Data were converted to Newtons of force using a calibration factor derived from known weights before the study. The system could detect forces down to the level of $0.0016 \mathrm{~N}$. Force data were analyzed using a custommade program written in LabVIEW (National Instruments) and MATLAB (MathWorks). The time series data were digitally filtered using a fourthorder Butterworth filter with a $30 \mathrm{~Hz}$ low-pass cutoff.

\section{Procedures}

Before testing, each participant's maximum voluntary contraction (MVC) was calculated separately for each hand using the average of the maximum force output during three trials in which participants pressed as hard as they could on a dynamometer (Sammons Preston Rolyan). During precision grip force testing, participants viewed a horizontal white force bar that moved upward with increased force and downward with decreased force and a static target bar that was red during rest and turned green to cue the participant to begin pressing at the beginning of each trial (Fig. 1C). Participants received two instructions: (1) press the load cells as quickly as possible when the red target bar turns green; and (2) keep pressing so that the force bar stays as steady as possible at the level of the green target bar. Trials were $15 \mathrm{~s}$ in duration and were alternated with 15 s rest periods. Participants completed two experiments; experiment order was counterbalanced across participants.

Experiment 1. During the first experiment, the target force level was varied to assess the effect of changing motor demands on visuomotor 


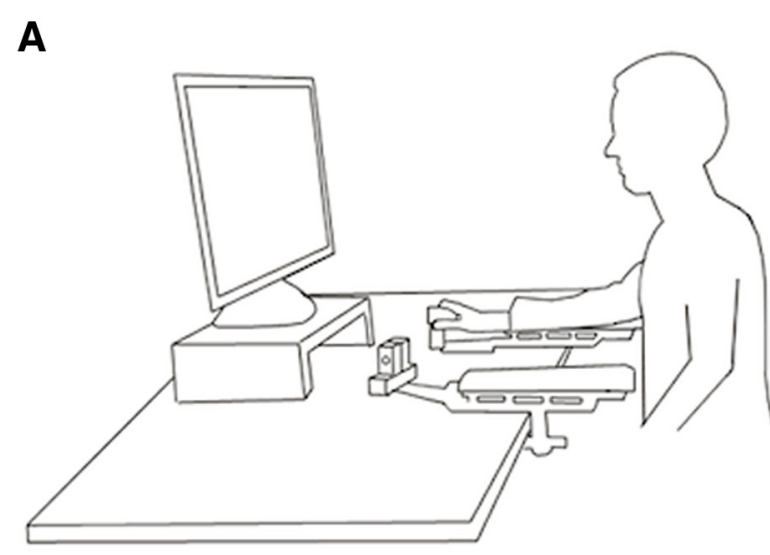

B
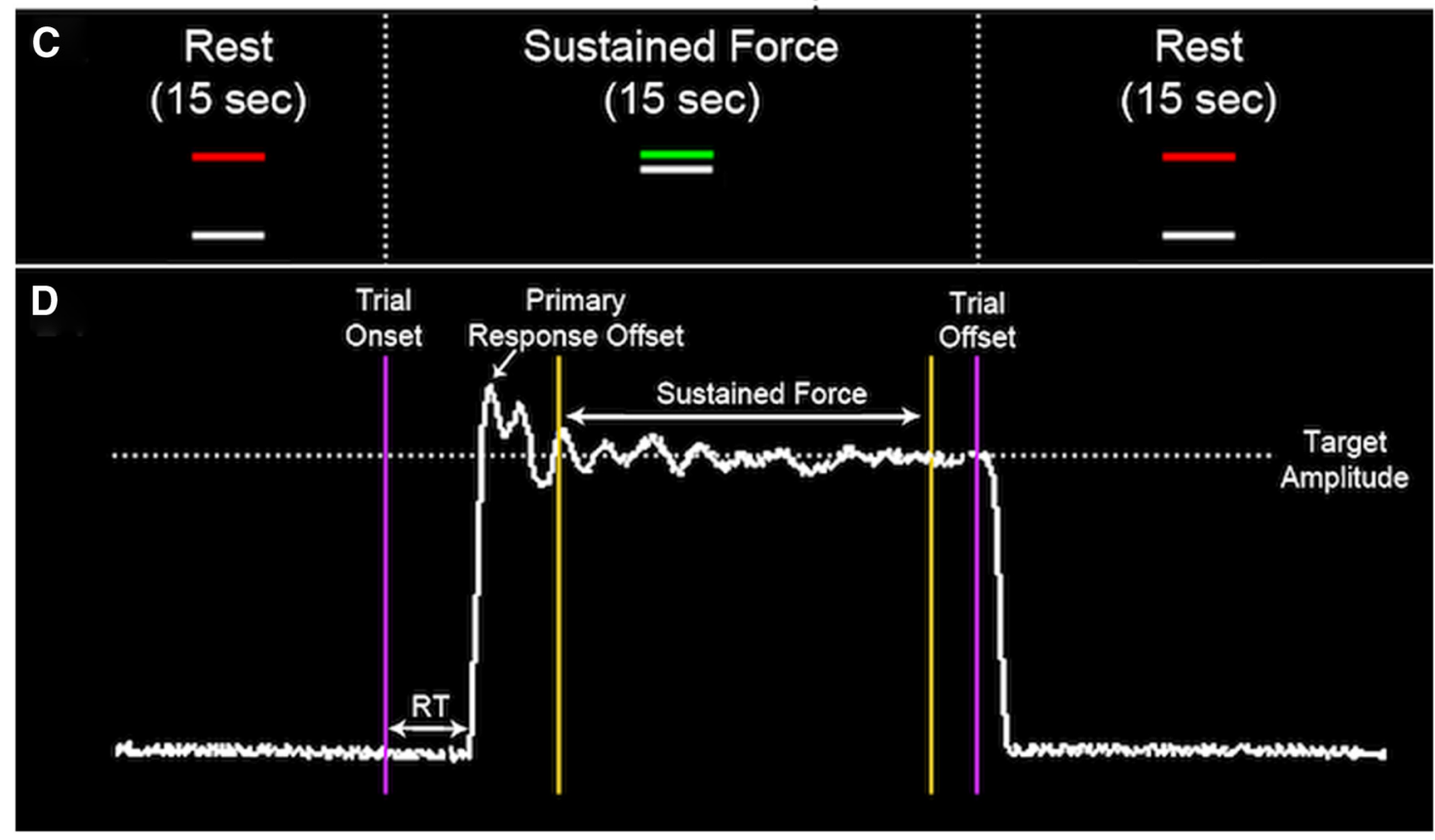

Figure 1. Precision grip force experiments. $A$, Schematic of the experimental setup for both precision grip force tasks. Participants were seated in front of a monitor while resting their arm in a custom device. $\boldsymbol{B}$, Schematic of a subject pressing on opposing load cells with their index finger and thumb. $\boldsymbol{C}$, Stimulus presentation showing target (red) and force (white) lines during rest. To begin each trial, the red target line turned green to cue the subject to begin pressing on the load cells. Participants sustained as constant a force level as possible for $15 \mathrm{~s}$. D, Sample force trace showing the subphases of each force trial that were scored, including the RT, the primary response, and the sustained force period.

performance. Participants completed three trials with each hand at 5, 25, 45,65 , and $85 \%$ of their MVC. The reaction time (RT), accuracy, peak rate of force increase, and duration of participants' initial (i.e., primary) force pulses were examined (Fig. 1D). The onset of force was identified when force level exceeded twice the baseline noise level in recordings. The offset of the primary response was marked at the first zero-crossing in the trace of the first derivative. The accuracy of the primary response was calculated as the percentage of the maximum force level at primary response offset relative to the target force level. Therefore, an accuracy percentage $>100$ indicated that the participant overshot the target, whereas an accuracy percentage $<100$ indicated that their primary response was less than the target force level. The visual gain (described below) was held constant at $1^{\circ}$ for all trials of experiment 1 .

To examine sustained visuomotor output, the force time series was marked excluding the first $2 \mathrm{~s}$ and last $1 \mathrm{~s}$ of force generation for each trial. Trials in which participants responded late or terminated force production before $6 \mathrm{~s}$ were not included in the analyses (Robichaud et al., 2005). The within-trial SD of the time series was calculated to examine force variability. Force data were linearly detrended to account for systematic changes in mean force over the course of the trial. To examine the time- dependent structure of the time series, the approximate entropy (ApEn) was calculated for each trial (Pincus and Goldberger, 1994; Slifkin and Newell, 1999; Vaillancourt et al., 2001). ApEn returns a value between 0 and 2 , reflecting the predictability of future values in a time series based on previous values. For example, a sine wave has accurate short- and long-term predictability and this corresponds to an ApEn value near 0 . High irregularity of the data, reflective of the independence of each force value, returns an ApEn value near 2. We used the same algorithm and parameter settings for these calculations $(m=2 ; r=0.2 \times \mathrm{SD}$ of the signal) as in previous work (Vaillancourt and Newell, 2000).

Experiment 2. A second test was conducted to assess the relationship between the gain of visual feedback and sustained force output. Visual gain was varied by changing the vertical distance the force bar moved in response to changes in force output. For example, the force bar moved upward $0.06 \mathrm{~mm}$ per $1 \mathrm{~N}$ increase in force at the smallest visual gain, whereas it moved upward $72.52 \mathrm{~mm}$ for every $1 \mathrm{~N}$ increase in force at the largest visual gain. We tested the following visual gains (measured in degrees of visual angle): $0.018,0.059,0.192,0.623,2.023,6.658$, and $21.127^{\circ}$. Visual gain was manipulated to ensure that we obtained values above and below $1^{\circ}$ based on our previous work showing that increases in 
visual gain below $1^{\circ}$ have a large effect on the SD of force (Vaillancourt et al., 2006a; Coombes et al., 2010). Because visual feedback is believed to have minimal effect on initial force pulses (Young and Zelaznik, 1992), we only examined the sustained period of the force time series during the visual gain experiment. Three trials were administered for each hand at each visual gain. The target was fixed at $15 \%$ of each individual's MVC for all trials of Experiment 2.

The power spectrum for each subject's force time series was computed in MATLAB 8.0 using Welch's averaged periodogram method with a non-overlapping 1024-point Hanning window. Data were sampled at $200 \mathrm{~Hz}$ with a $0.195 \mathrm{~Hz}$ bin width. The power in each frequency bin represented the force level of oscillations that occurred within the specified frequency range. Changes in power as a function of force level and visual gain were examined by calculating the amount of power in three 4 $\mathrm{Hz}$ bandwidths from 0 to $12 \mathrm{~Hz}$ for each participant at each condition. The lowest frequency bin $(0-4 \mathrm{~Hz})$ has been shown to be associated with visual feedback processes (Miall et al., 1985; Sosnoff and Newell, 2005). Higher frequencies up to $12 \mathrm{~Hz}$ during grip force control reflect faster feedforward processes (Sosnoff and Newell, 2005; Hu and Newell, 2010).

\section{Clinical measures}

The ADOS and ADI were used to assess social-communication abilities and restricted, repetitive behaviors in ASD. The ADOS is a semistructured observation of patient behavior, whereas the ADI is a parent/ caregiver interview focused on patients' developmental history and current behavior. ADOS ratings were used to examine the relationships between precision force performance and diagnostic features of ASD. Because the ADI is a parent/caregiver interview and thus does not provide direct measurements of individuals' behavior, the majority of ADI scales were not examined in relation to precision force. To determine whether our measures of precision force were related to clinical signs of motor abnormality in ASD, we assessed the correlations between force variables and the ADI item probing whether there was anything unusual about the way children walked when they were aged $4-5$ years. For all ADOS and ADI ratings, higher scores reflect greater abnormality. The Vineland Adaptive Behavior Scales-II (Vineland; Sparrow et al., 2005) also was used to assess clinical signs of motor abnormalities. The Vineland is a semi-structured parent/caregiver interview used to assess abilities in the areas of socialization, communication, and daily living activities. Visuomotor performance was examined in relation to the handwriting subscale of the Vineland. For the Vineland, lower scores indicate less developed abilities.

\section{Data analysis}

Dependent measures from the precision force tests were placed in separate three-way ANOVA models including the between-subject factor diagnostic group (ASD vs controls) and two within-subjects factors as repeated measures: hand tested (right vs left) and condition (for Experiment 1, this included the five force levels; for Experiment 2, this included the seven levels of visual gain). Therefore, separate ANOVA models were completed for each experiment and each measure of precision force. All group effects are reported along with significant main effects of hand or condition and significant interactions. Pearson's correlation coefficients were used to examine the interrelationships of the different force measures and the relationships between force measures found to be different between groups and age, IQ, ADOS, ADI, and Vineland clinical ratings. Pearson's $r$ values were converted to $Z$ values using a Fisher's transformation so that the strength of correlations between force and demographic characteristics could be directly compared between the ASD and control groups.

\section{Results}

Performance was similar across trials for each force variable, and no trial $\times$ group interactions were seen for force performance (all $|F|<1.80, p>0.184)$. Therefore, performance was averaged across trials for all analyses.

\section{Initial force pulse characteristics}

Participants' initial force pulses overshot target force levels, and the degree to which they overshot targets was greater at lower
A

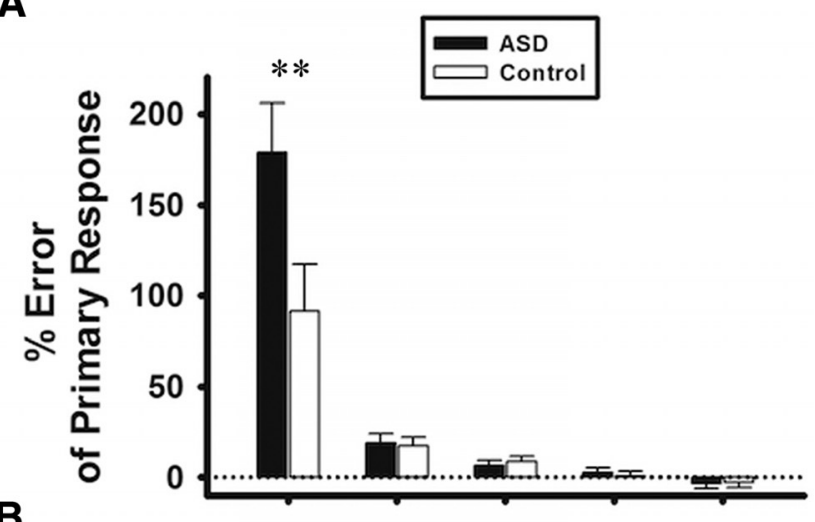

$B$

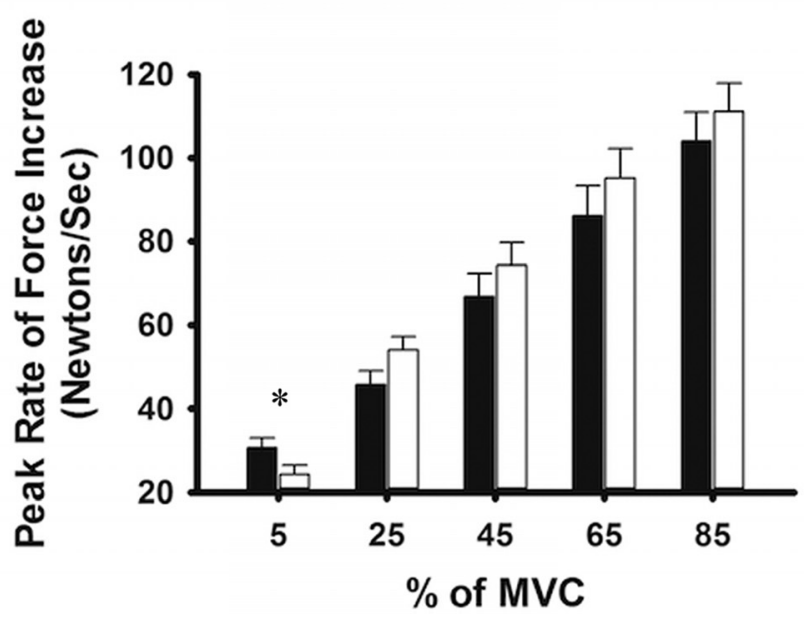

Figure 2. The accuracy and peak rate of force increase of primary pulses as a function of target force level for participants with ASD and healthy controls. $\boldsymbol{A}$, Although both groups showed a transient force overshoot during trials in which the target force level was $5 \%$ of their MVC, the degree to which participants exceeded target force levels was greater for participants with ASD compared with healthy controls. $\boldsymbol{B}$, Peak rate of force increase was greater in participants with ASD at $5 \%$ of their MVC but no different from controls at larger force levels. ${ }^{*} p<$ $0.05 ;{ }^{* *} p<0.01$.

force levels $\left(F_{(4,52)}=50.19, p=10^{-30}\right)$. The difference between groups in the accuracy of initial pulses across force levels approached but did not reach significance $\left(F_{(1,55)}=3.74, p=\right.$ $0.058)$. However, participants with ASD overshot targets more than controls at the lowest (5\%) but not higher force levels (Fig. 2; group $\times$ force level interaction, $\left.F_{(4,52)}=5.65, p=0.019\right)$.

Participants showed greater peak rates of force increase at higher force levels compared with lower force levels $\left(F_{(4,52)}=\right.$ 84.32, $\left.p=10^{-22}\right)$. There were no differences between participants with ASD and healthy controls in the rate of force increase across force levels $\left(F_{(1,55)}=0.41, p=0.525\right)$, but participants with ASD showed an abnormal rate of force increase across different force levels. During 5\% of MVC trials, participants with ASD showed greater rates of force increase compared with controls, whereas they demonstrated similar rates of force increase at all other force levels (Fig. 2; group $\times$ force level interaction, $\left.F_{(4,52)}=3.61, p=0.011\right)$. The duration of primary pulses scaled with force level $\left(F_{(4,52)}=47.73, p=10^{-17}\right)$, and participants with ASD showed primary pulse durations similar to controls across force levels $\left(F_{(4,52)}=0.81, p=0.371\right)$. Force onset RT did not vary as a function of target force level $\left(F_{(4,52)}=0.67, p=0.619\right)$, and there were no group differences in force onset RTs $\left(F_{(1,55)}=\right.$ 2.91, $p=0.094)$. 
A
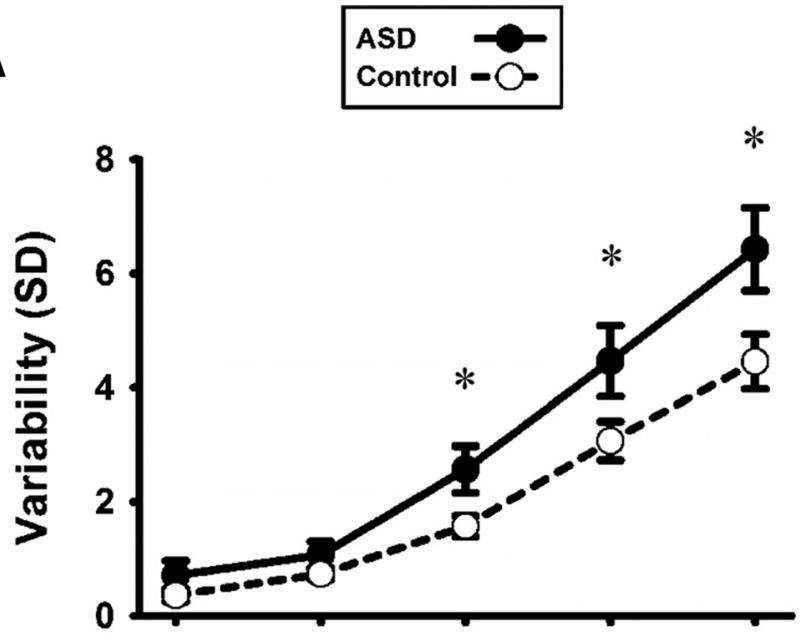

B

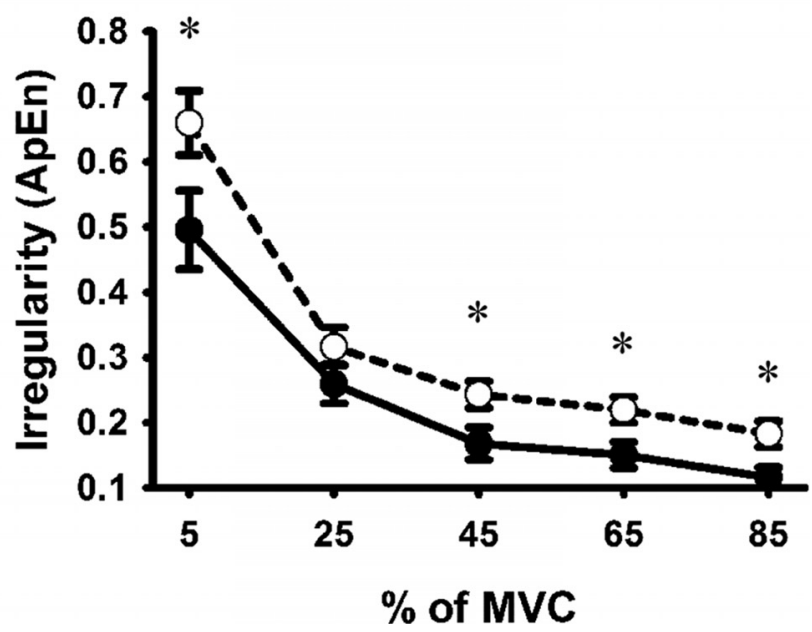

Figure 3. Sustained force performance for participants with ASD and healthy control participants across different force levels. $\boldsymbol{A}$, Participants with ASD showed increased force variability (SD) compared with healthy controls, especially at larger force levels. $\boldsymbol{B}$, ApEn of participants with ASD was lower than for healthy control participants, suggesting that they showed less irregularity in the structure of their sustained force output. ${ }^{*} p<0.05$.

\section{Sustained force characteristics}

During Experiment 1, participants' mean sustained force was greater at higher force levels $\left(F_{(4,52)}=72.17, p=10^{-18}\right)$, and there were no differences in mean force levels between groups $\left(F_{(1,55)}=1.48, p=0.228\right)$. This suggests that both groups were able to complete the task. Participants' sustained force output was more variable at higher force levels compared with lower force levels $\left(F_{(4,52)}=39.06, p=10^{-15}\right)$. Participants with ASD showed higher sustained force variability than controls (Fig. 3; $F_{(1,55)}=6.07, p=0.017$ ), especially at larger force levels (group $\times$ force level interaction, $\left.F_{(4,52)}=3.20, p=0.014\right)$.

During Experiment 2, participants' mean force was lower at higher visual gains compared with smaller visual gains $\left(F_{(6,50)}=\right.$ 18.12, $\left.p=10^{-5}\right)$. Participants with ASD and controls did not differ in their mean force levels across visual gains $\left(F_{(1,55)}=0.95\right.$, $p=0.335)$. Force SD decreased with increasing visual gain up to $1^{\circ}$ of visual angle and then increased at larger visual gains (Fig. 4; quadratic effect of visual gain, $F_{(1,55)}=55.10, p=10^{-9}$ ). Participants with ASD showed increased force SD compared with controls $\left(F_{(1,55)}=7.15, p=0.010\right)$, particularly at the smallest and largest visual gains (group $\times$ visual gain quadratic interaction, $\left.F_{(1,55)}=10.49, p=0.002\right)$.
A
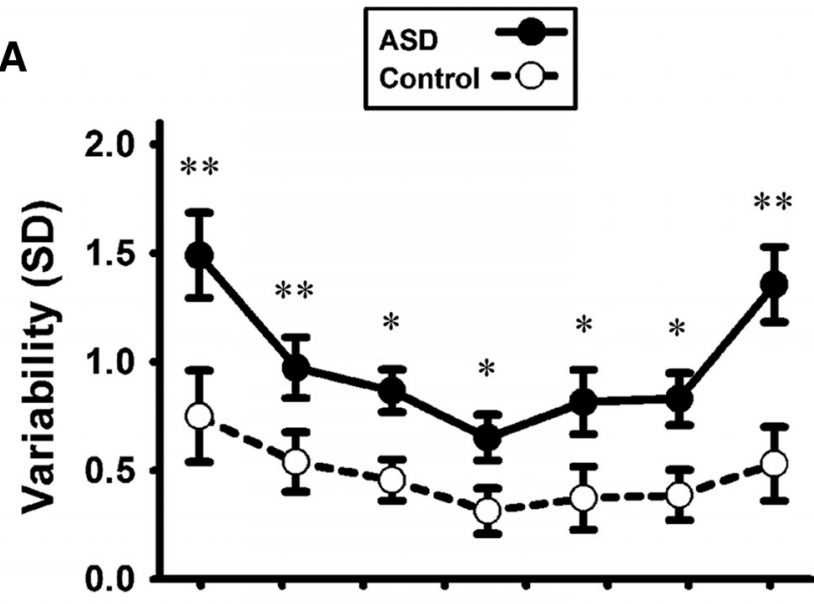

B

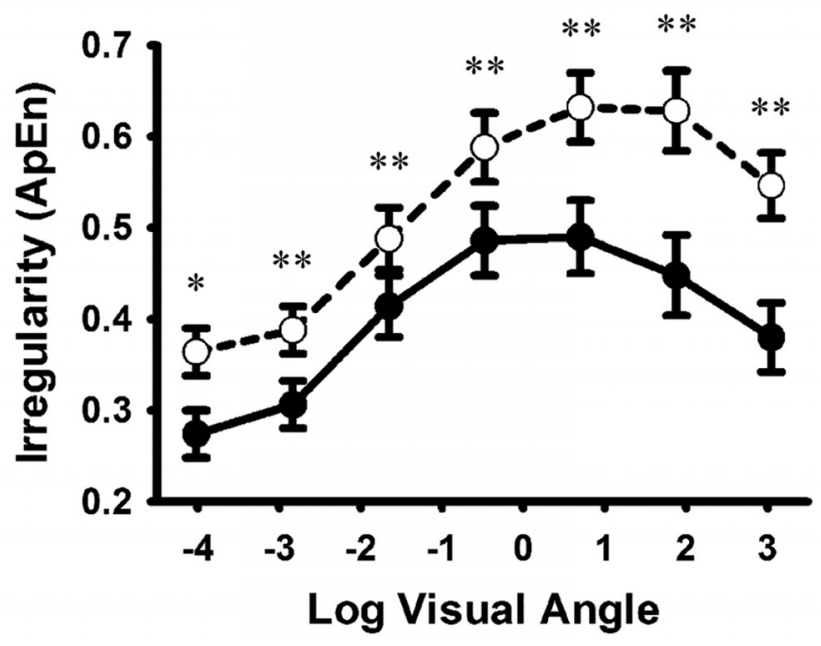

Figure 4. Sustained force performance for participants with ASD and healthy control participants across different visual gains. A, Participants with ASD showed increased force variability (SD) compared with healthy controls, especially at smaller and larger visual gains. $\boldsymbol{B}$, ApEn of participants with ASD was lower than for healthy controls, and this deficit was more severe at larger visual gains. ${ }^{*} p<0.05 ;{ }^{* *} p<0.01$.

The time and frequency structure of sustained force output Force structure became less irregular (ApEn decreased) with increases in force level (Fig. $3 ; F_{(4,52)}=77.56, p=10^{-41}$ ). Participants with ASD showed reduced ApEn compared with controls across force levels (Fig. $3 ; F_{(1,55)}=4.65, p=0.035$ ). The group $\times$ force level interaction approached but did not reach significance $\left(F_{(4,52)}=2.04, p=0.089\right)$. During the visual gain experiment, ApEn increased with increases in visual gain up to $2.023^{\circ}$ but then decreased at the largest gain levels (Fig. 4; visual gain quadratic function, $\left.F_{(6,50)}=95.63, p=10^{-13}\right)$. Participants with ASD showed reduced ApEn compared with controls across different visual gains $\left(F_{(1,55)}=7.44, p=0.009\right)$, especially at the largest visual gains (visual gain $\times$ group interaction, $F_{(6,50)}=2.71, p=$ 0.014).

Spectral analyses indicated that the majority of power in the sustained force time series was in the $0-4 \mathrm{~Hz}$ range across force levels (Fig. 5; main effect of frequency bin, $F_{(4,52)}=74.50, p=$ $\left.10^{-12}\right)$. Power increased with increases in force level for all frequency bins (main effect of force level, $F_{(2,54)}=90.23, p=$ $10^{-14}$ ), particularly at $0-4 \mathrm{~Hz}$ (frequency bin $\times$ force level interaction, $\left.F_{(8,48)}=69.46, p=10^{-12}\right)$. Individuals with ASD showed 


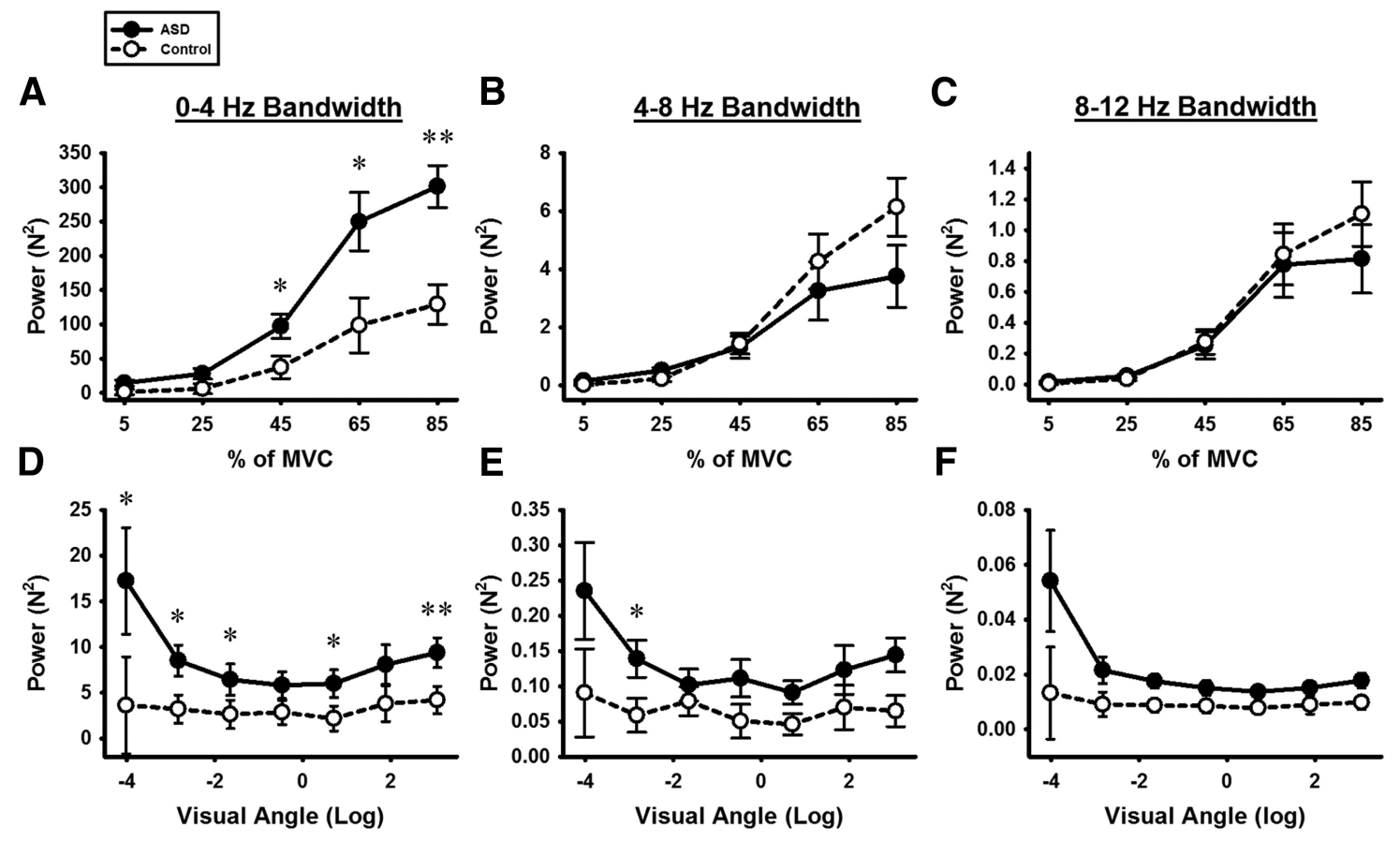

Figure 5. Power spectra across $0-4,4-8$, and $8-12 \mathrm{~Hz}$ bandwidths in individuals with ASD and healthy controls. $A$, Participants with ASD showed elevated power at $0-4 \mathrm{~Hz}$ across force levels. They showed reduced $4-8 \mathrm{~Hz}$ power $(\boldsymbol{B})$ and $8-12 \mathrm{~Hz}$ power $(\boldsymbol{C})$ compared with controls at the largest force levels, but these differences were not significant. Participants with ASD showed increases in $0-4 \mathrm{~Hz}$ power $(\boldsymbol{D}), 4-8 \mathrm{~Hz}$ power $(\boldsymbol{E})$, and $8-12 \mathrm{~Hz}$ power $(\boldsymbol{F})$ across visual gains, but increases in $0-4 \mathrm{~Hz}$ power were more severe than those for $4-8$ or $8-12 \mathrm{~Hz}$. ${ }^{*} p<0.05 ;{ }^{* *} p<0.01$.

an overall increase in power compared with controls $\left(F_{(1,55)}=\right.$ 15.38, $\left.p=10^{-4}\right)$, but individuals with ASD showed elevated power only at $0-4 \mathrm{~Hz}$ and similar or reduced power compared with controls at $4-8$ and $8-12 \mathrm{~Hz}$ (group $\times$ frequency bin interaction, $\left.F_{(1,55)}=15.87, p=10^{-4}\right)$. Increased $0-4 \mathrm{~Hz}$ power in ASD was greater at higher force levels (group $\times$ frequency bin $\times$ force level interaction, $\left.F_{(1,55)}=12.76, p=0.001\right)$.

For the visual gain experiment, the greatest amount of total power was in the $0-4 \mathrm{~Hz}$ range (Fig. 5; main effect of frequency bin, $\left.F_{(6,50)}=12.39, p=0.001\right)$. Power across frequency bins was greatest at the smallest visual gains (main effect of gain, $F_{(6,50)}=$ 2.50, $p=0.032$ ). Across visual gains, participants with ASD showed increased power compared with controls (Fig. $5 ; F_{(1,55)}=$ 5.47, $p=0.022$ ) especially at $0-4 \mathrm{~Hz}$ (group $\times$ frequency bin interaction, $\left.F_{(1,55)}=5.43, p=0.005\right)$.

\section{Precision force interrelationships and clinical/demographic characteristics}

Force characteristics

For healthy controls, increased initial pulse overshoot was associated with reduced ApEn $\left(r_{(27)}=-0.43, p=0.020\right)$. Increased force variability was associated with reduced ApEn (force level experiment, $r_{(27)}=-0.70, p=10^{-7}$; visual gain experiment, $r_{(27)}=$ $-0.72, p=10^{-7}$ ) and increased $0-4 \mathrm{~Hz}$ power (force level experiment, $r_{(27)}=0.70, p=10^{-7}$; visual gain experiment, $r_{(27)}=0.69$, $\left.p=10^{-6}\right)$. Reduced ApEn also was associated with increased $0-4$ $\mathrm{Hz}$ power (force level experiment, $r_{(27)}=-0.34, p=0.071$; visual gain experiment, $\left.r_{(27)}=-0.38, p=0.042\right)$. Increased $4-8 \mathrm{~Hz}$ power was associated with increased $8-12 \mathrm{~Hz}$ power (force level experiment, $r_{(27)}=0.78, p=10^{-8}$; visual gain experiment, $r_{(27)}=0.35$, $p=0.063)$. No other correlations between force measures were significant for controls (all $|r|<0.25, p>0.191$ ).

Increased overshoot of initial force pulses was associated with increased peak rates of force increase in ASD $\left(r_{(26)}=0.54, p=\right.$ $0.005)$. Increased sustained force variability was associated with lower ApEn (force level experiment, $r_{(26)}=-0.62, p=10^{-5}$; visual gain experiment, $r_{(26)}=-0.64, p=10^{-5}$ ) and increased $0-4 \mathrm{~Hz}$ power (force level experiment, $r_{(26)}=0.89, p=10^{-10}$; visual gain experiment, $\left.r_{(26)}=0.90, p=10^{-10}\right)$. Reduced ApEn was related to increased $0-4 \mathrm{~Hz}$ power (force level experiment, $r_{(26)}=-0.51, p=0.009$; visual gain experiment, $r_{(26)}=-0.38$, $p=0.046)$. Increased $0-4 \mathrm{~Hz}$ power was associated with increased $4-8 \mathrm{~Hz}$ power (force level experiment, $r_{(26)}=0.52, p=$ 0.007; visual gain experiment, $r_{(26)}=0.94, p=10^{-7}$ ). Increased $4-8 \mathrm{~Hz}$ power also was associated with increased $8-12 \mathrm{~Hz}$ power for the visual gain experiment only $\left(r_{(26)}=0.97, p=10^{-14}\right)$. No other force variables were significantly correlated for individuals with ASD (all $|r|<0.30, p>0.114$ ). There were no differences in the strengths of the relationships between force variables for individuals with ASD and controls (all Fisher's $Z$ $<1.00, p<0.332$ ).

\section{ASD features}

Increased overshoot of primary force pulses in ASD was associated with more severe social-communication abnormalities (Fig. $\left.6 ; r_{(24)}=0.41, p=0.028\right)$, repetitive behaviors $\left(r_{(24)}=0.39, p=\right.$ $0.042)$, and handwriting impairments $\left(r_{(17)}=-0.65, p=0.002\right)$. Reduced ApEn in ASD was associated with more severe socialcommunication abnormalities (Fig. 6; force level experiment, $r_{(26)}=-0.49, p=0.009$; visual gain experiment, $r_{(26)}=-0.45$, $p=0.008$ ) and handwriting impairments (force level experiment, $r_{(17)}=0.60, p=0.006$; visual gain experiment, $r_{(17)}=0.46$, $p=0.040)$. Decreased power in the $8-12 \mathrm{~Hz}$ bin across force levels was associated with more severe repetitive behaviors in $\operatorname{ASD}\left(r_{(27)}=-0.38, p=0.036\right)$. Among the individuals with ASD, those with a history of gait abnormalities showed lower ApEn than those with no history of gait abnormality (Fig. 6; force level experiment, $t_{(23)}=3.05, p=0.006$; visual gain experiment, $\left.t_{(23)}=2.24, p=0.035\right)$. 
A

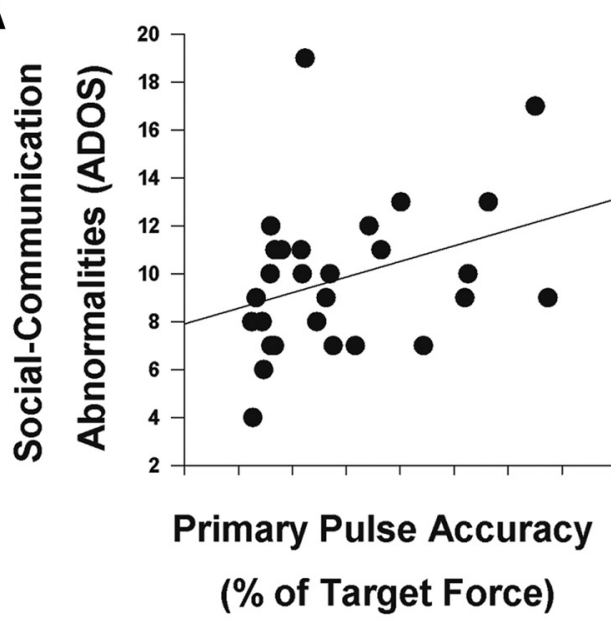

C

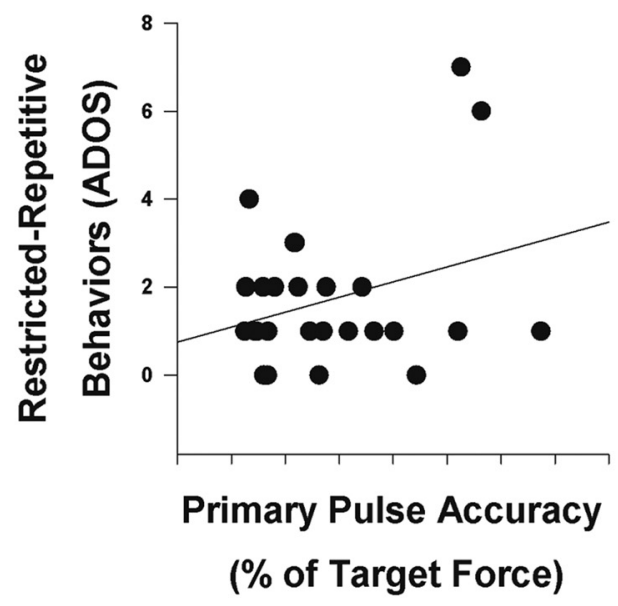

E

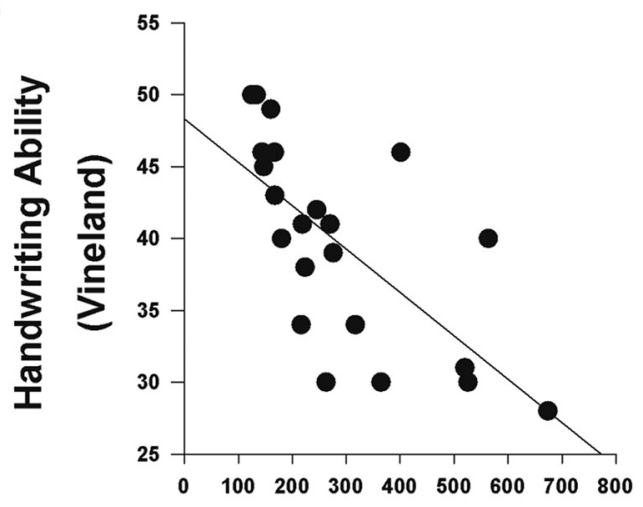

Primary Pulse Accuracy
B

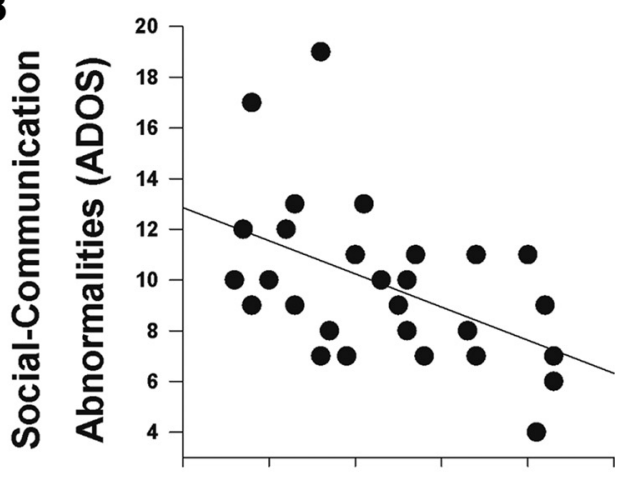

ApEn

D

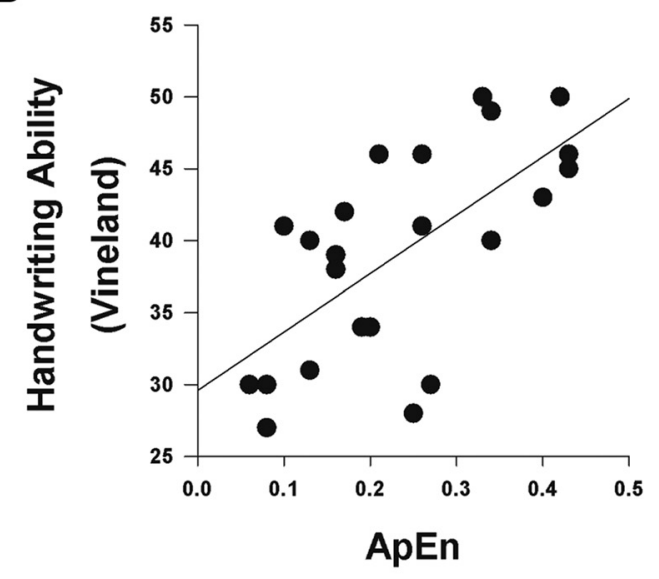

$\mathbf{F}$

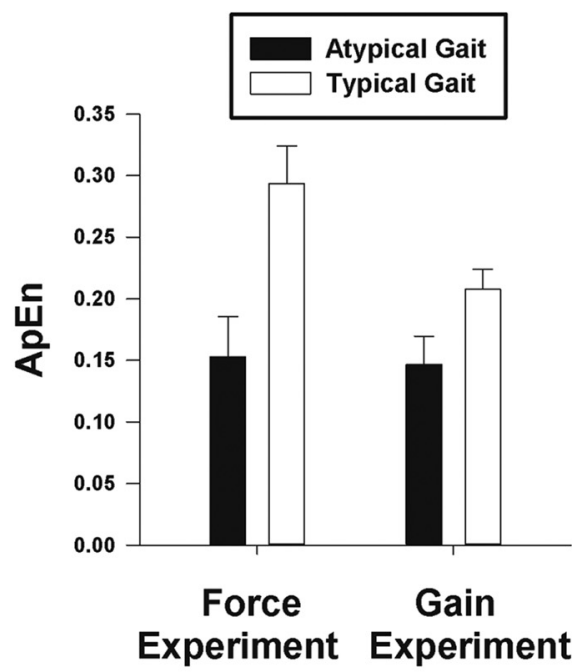

( $\%$ of Target Force)

Figure 6. Relationships between precision force performance and clinical characteristics of individuals with ASD. Increased overshoot of primary pulses at $5 \%$ of MVC was associated with more severe clinically rated social-communication abnormalities $(\boldsymbol{A})$, restricted, repetitive behaviors $(\boldsymbol{C})$, and handwriting impairments $(\boldsymbol{E})$ in ASD. Reduced ApEn during sustained precision force was associated with more severe clinically rated social-communication abnormalities $(\boldsymbol{B})$ and handwriting impairments $(\boldsymbol{D})$. $\boldsymbol{F}$, Individuals with ASD with a history of gait abnormalities as rated on the ADI showed reduced ApEn across both force levels and levels of visual gain relative to those individuals with ASD who did not have a history of gait abnormalities. 
Age

For healthy controls, increased age was associated with reduced force variability (force level experiment, $r_{(27)}=-0.37, p=0.050$; visual gain experiment, $\left.r_{(27)}=-0.47, p=0.013\right)$, increased ApEn (force level experiment, $r_{(27)}=0.65, p=10^{-4}$; visual gain experiment, $\left.r_{(27)}=0.64, p=10^{-4}\right)$, decreased power at $0-4 \mathrm{~Hz}$ across visual gains $\left(r_{(27)}=-0.47, p=0.003\right)$, and increased power at $8-12 \mathrm{~Hz}$ across force levels $\left(r_{(27)}=0.40, p=0.013\right)$. There were no age-related differences in the accuracy of primary pulses $\left(r_{(27)}=-0.27, p=0.111\right)$.

For participants with ASD, increased age was associated with increased ApEn $\left(r_{(26)}=0.49, p=0.011\right)$ and increased power at $8-12 \mathrm{~Hz}$ across force levels $\left(r_{(27)}=0.49, p=0.003\right)$. Age was not associated with the accuracy of primary pulses, force variability, or other frequency measures for participants with ASD (all $|r|<$ $0.21, p>0.153$ ). Comparisons of the strength of relationships between age and force performance indicated trends for the controls to show stronger age-related reductions in force variability during the gain experiment (Fisher's $Z=1.32, p=0.093$ ) and age-related increases in ApEn during the gain experiment (Fisher's $Z=1.56, p=0.059$ ) than individuals with ASD.

IQ

For individuals with ASD, the relationship between full-scale IQ and force variability during the force level experiment approached significance $\left(r_{(27)}=-0.36, p=0.065\right)$. Other visuomotor variables were not related to IQ for either group (all $|r|<$ $0.29, p>0.152)$.

\section{Discussion}

We present three novel findings in this study. First, individuals with ASD made less accurate initial force contractions than controls, implicating alterations in feedforward motor control mechanisms. Second, sustained force output was more variable in ASD, suggesting that feedback control also is compromised. Importantly, increased overshoot of initial force pulses and increased sustained force variability in ASD were not associated with each other, suggesting that feedforward and feedback deficits may be relatively independent. Last, reduced accuracy of primary contractions and reduced irregularity of sustained force output were related to more severe ASD symptoms. These results suggest that feedforward and feedback motor control alterations are associated with the severity of the defining clinical features of ASD.

\section{Feedforward control of force output}

The precision of initial grasping forces depends on feedforward mechanisms that operate before sensory feedback can be translated into corrective adjustments (Ghez et al., 1991). Anterior cerebellar lobules I-V provide predictive commands to primary motor cortex to modulate the timing and amplitude of initial agonist and antagonist muscle contractions (Vilis and Hore, 1980). Initial force contractions made by participants with ASD showed a larger overshoot compared with controls at small force levels, suggesting that predictive commands generated in lobules $\mathrm{I}-\mathrm{V}$ are amplified during rapid, precise contractions.

Our finding that feedforward deficits in ASD are specific to low force contractions may help resolve inconsistencies among previous studies. Larger force contractions are longer in duration compared with those generated at lower force levels, which allows participants more time to make online corrections (Wolpert and Miall, 1996; Desmurget and Grafton, 2000). As suggested previously, individuals with ASD may compensate for error in their initial specification of muscular forces when the duration of the movement is long enough for visual feedback to be used to make reactive adjustments (Glazebrook et al., 2006). Our findings also advance previous studies of precision grip in ASD (Gowen and Miall, 2005; David et al., 2009, 2012) by indicating that feedforward control of force output is disrupted even when the coordination of distinct muscle groups is not required, implicating planning rather than joint-coordination functions of the cerebellum in patients' commonly seen dyspraxia (Dziuk et al., 2007).

\section{Feedback control of sustained force}

During sustained force contractions, the cerebellum transforms visual inputs into corrective motor commands that reduce the variability of motor output (Vaillancourt et al., 2003, 2006b). During precision gripping, cerebellar lobules V-VI and Crus I/II increase their activity level at higher force amplitudes (Spraker et al., 2012). Our finding that force variability elevations in ASD scaled with increases in force amplitude suggests that the variability reducing function of the posterior cerebellum is disrupted.

Increases in force variability at higher force levels suggest that the severity of visuomotor abnormalities in ASD is dependent, in part, on the level of demand on the motor system. Patients' increased variability also appears to reflect a bias in their underlying motor control strategy. Compared with controls, individuals with ASD showed elevations in $0-4 \mathrm{~Hz}$ power that scaled with force level. Thus, as the demands on the motor output system are increased, individuals with ASD become more reliant on slower feedback mechanisms. This is a particularly inefficient strategy during large force contractions for which rapid corrections are needed to reduce larger errors in motor output. As the time delay of the motor response is increased, there is greater drift from the target point. Previous studies have suggested that individuals with ASD show increased reliance on proprioceptive feedback information during motor learning (Haswell et al., 2009; Izawa et al., 2012). Our results complement these findings by showing an increased reliance on visual feedback and a reduced ability to accurately translate visual feedback into corrective motor commands during precision gripping.

Increases in force variability in ASD also varied in relation to visual gain, implicating distinct visuomotor brain circuits (Poon et al., 2013). When visual gain is increased, inferior parietal lobule (IPL) activity increases to translate visual error information to the posterior cerebellum (Coombes et al., 2011). The finding that force variability increases in ASD were more severe at higher gain levels suggests that patients have a reduced ability to process rapid visual feedback information, implicating alterations in IPL-cerebellar processes. Patients' reduced ApEn at higher gain levels compared with controls suggests that they use a less dynamic control strategy to adjust force output in response to rapid changes in visual error information. These results are consistent with previous studies showing increased variability of eye (Gepner and Mestre, 2002b) and postural (Gepner and Mestre, 2002a) movements and suggest that individuals with ASD are not able to make accurate visuomotor corrections when visual feedback inputs are presented rapidly.

Individuals with ASD also showed disproportionate increases in force variability when visual gain was degraded. Visual information from extrastriate cortices projects to the parietal cortex and then the posterior cerebellum before new motor commands are generated in the primary motor cortex (Stein and Glickstein, 1992). Our results suggest that parieto-cerebellar circuits are less able to compensate for reduced visual information in ASD, and 
patients are more dependent on precise visual feedback to control continuous motor actions.

The profile of feedforward and feedback motor control abnormalities seen here in ASD is similar to that documented previously in patients with cerebellar lesions (Babin-Ratté et al., 1999; Fellows et al., 2001; Rost et al., 2005; Brandauer et al., 2008). Furthermore, studies of ASD have consistently documented cerebellar anomalies, including Purkinje cell pathology (Amaral et al., 2008), abnormal levels of GAD65 and GAD67 mRNA expression in Purkinje cells and interneurons (Fatemi et al., 2002; Yip et al., 2007, 2008), reduced white matter integrity (Bloss and Courchesne, 2007; Catani et al., 2008; Suzuki et al., 2013), and reduced functional activation during motor tasks (Allen et al., 2004; Müller et al., 2004; Takarae et al., 2007; Mostofsky et al., 2009). Based on these findings, we posit that alterations intrinsic to anterior cerebellar circuits lead to feedforward motor control dysfunctions in ASD, and abnormalities of posterior cerebellar circuits disrupt the translation of visual feedback into precise motor corrections. This interpretation is consistent with recent findings that individuals with ASD show a reduced rate of cerebellar-dependent visuomotor learning when adapting eyemovement amplitudes to systematic visual errors (Johnson et al., 2013; Mosconi et al., 2013).

Feedforward and feedback control deficits in ASD also may involve non-cerebellar mechanisms. Several previous ASD studies have suggested that cerebellar-dependent motor learning may be spared (Mostofsky et al., 2004; Gidley Larson et al., 2008), indicating that pathology may selectively disrupt only a subset of cerebellar circuits (Catani et al., 2008; Shukla et al., 2010) or that alternative networks may developmentally compensate for cerebellar dysfunctions (Takarae et al., 2007). Reduced anatomical and functional connectivity has been documented frequently in ASD (Jeong et al., 2014; Hernandez et al., 2015), and thus it is possible that reduced visuomotor control may reflect more generalized deficits in communication across distal brain regions. Direct, in vivo measurements of cortical and cerebellar anatomy and function in relation to visuomotor ability are needed to confirm the role of cerebellar pathology in feedforward and feedback motor control deficits in ASD and to identify the precise circuits that are disrupted.

\section{Associations between visuomotor impairments and ASD severity}

Reductions in initial force accuracy and force irregularity each were associated with more severe social-communication impairments in ASD. Sensorimotor processes mature rapidly during the first years of life (Gernsbacher et al., 2008; Gallese et al., 2009, 2013; LeBarton and Iverson, 2013), and their disruption may interfere with developing abilities to imitate others' actions or learn critical language and social skills-processes that require accurate internal action representations and online feedbackbased modifications (Iacoboni and Dapretto, 2006; Cattaneo et al., 2007; Williams et al., 2007). This hypothesis is supported by findings that disruptions of sensorimotor abilities in infancy in ASD are the best early predictors of children's subsequent social and cognitive development (Sutera et al., 2007). Our finding that motor deficits in ASD show a trend to become more severe over development suggests that they may persist throughout the lifetime.

Visuomotor deficits and social-communication alterations also may be associated because they stem from common neurodevelopmental mechanisms. The high prevalence of ASD in children with cerebellar disease (Shevelkin et al., 2014) and increasing evidence that the cerebellum is critical for both motor and non-motor skills implicate this structure in multiple aspects of the disorder (Stoodley and Schmahmann, 2009; Fatemi et al., 2012). We found that visuomotor deficits in ASD were associated with early motor abnormalities, suggesting that studies of infant motor development may provide insights into the earliest manifestations of ASD and potentially provide a tool to facilitate early detection (Nickel et al., 2013).

In summary, we find evidence for deficits in both feedforward and feedback motor control processes that are related to the severity of social-communication abnormalities in ASD. Characterizing the dysfunctions in discrete cerebellar circuits that underpin feedforward and feedback control alterations in ASD may be informative for understanding the sensorimotor abnormalities and dyspraxia common in this disorder and the neural mechanisms contributing to the social-communication and cognitive features of ASD.

\section{References}

Allen G, Müller RA, Courchesne E (2004) Cerebellar function in autism: functional magnetic resonance image activation during a simple motor task. Biol Psychiatry 56:269-278. CrossRef Medline

Amaral DG, Schumann CM, Nordahl CW (2008) Neuroanatomy of autism. Trends Neurosci 31:137-145. CrossRef Medline

American Psychiatric Association (2013) Diagnostic and statistical manual of mental disorders, Ed 5. Arlington, VA: American Psychiatric Association.

Babin-Ratté S, Sirigu A, Gilles M, Wing A (1999) Impaired anticipatory finger grip-force adjustments in a case of cerebellar degeneration. Exp Brain Res 128:81-85. CrossRef Medline

Bloss CS, Courchesne E (2007) MRI neuroanatomy in young girls with autism: a preliminary study. J Am Acad Child Adolesc Psychiatry 46:515523. CrossRef Medline

Brandauer B, Hermsdörfer J, Beck A, Aurich V, Gizewski ER, Marquardt C, Timmann D (2008) Impairments of prehension kinematics and grasping forces in patients with cerebellar degeneration and the relationship to cerebellar atrophy. Clin Neurophysiol 119:2528-2537. CrossRef Medline

Bryson SE, Zwaigenbaum L, Brian J, Roberts W, Szatmari P, Rombough V, McDermott C (2007) A prospective case series of high-risk infants who developed autism. J Autism Dev Disord 37:12-24. CrossRef Medline

Catani M, Jones DK, Daly E, Embiricos N, Deeley Q, Pugliese L, Curran S, Robertson D, Murphy DG (2008) Altered cerebellar feedback projections in Asperger syndrome. Neuroimage 41:1184-1191. CrossRef Medline

Cattaneo L, Fabbri-Destro M, Boria S, Pieraccini C, Monti A, Cossu G, Rizzolatti G (2007) Impairment of actions chains in autism and its possible role in intention understanding. Proc Natl Acad Sci U S A 104:1782517830. CrossRef Medline

Chen-Harris H, Joiner WM, Ethier V, Zee DS, Shadmehr R (2008) Adaptive control of saccades via internal feedback. J Neurosci 28:2804-2813. CrossRef Medline

Cook JL, Blakemore SJ, Press C (2013) Atypical basic movement kinematics in autism spectrum conditions. Brain 136:2816-2824. CrossRef Medline

Coombes SA, Corcos DM, Sprute L, Vaillancourt DE (2010) Selective regions of the visuomotor system are related to gain-induced changes in force error. J Neurophysiol 103:2114-2123. CrossRef Medline

Coombes SA, Corcos DM, Vaillancourt DE (2011) Spatiotemporal tuning of brain activity and force performance. Neuroimage 54:2226-2236. CrossRef Medline

Daskalakis ZJ, Paradiso GO, Christensen BK, Fitzgerald PB, Gunraj C, Chen R (2004) Exploring the connectivity between the cerebellum and motor cortex in humans. J Physiol 557:689-700. CrossRef Medline

David FJ, Baranek GT, Giuliani CA, Mercer VS, Poe MD, Thorpe DE (2009) A pilot study: coordination of precision grip in children and adolescents with high functioning autism. Pediat Phys Ther 21:205-211. CrossRef Medline

David FJ, Baranek GT, Wiesen C, Miao AF, Thorpe DE (2012) Coordination of precision grip in 2-6 years-old children with autism spectrum disorders compared to children developing typically and children with developmental disabilities. Front Integr Neurosci 6:122. CrossRef Medline

De Jong M, Punt M, De Groot E, Minderaa RB, Hadders-Algra M (2011) 
Minor neurological dysfunction in children with autism spectrum disorder. Dev Med Child Neurol 53:641-646. CrossRef Medline

Desmurget M, Grafton S (2000) Forward modeling allows feedback control for fast reaching movements. Trends Cogn Sci 4:423-431. CrossRef Medline

Dziuk MA, Gidley Larson JC, Apostu A, Mahone EM, Denckla MB, Mostofsky SH (2007) Dyspraxia in autism: association with motor, social, and communicative deficits. Dev Med Child Neurol 49:734-739. CrossRef Medline

Elberling H, Linneberg A, Olsen EM, Houmann T, Rask CU, Goodman R, Skovgaard AM (2014) Infancy predictors of hyperkinetic and pervasive developmental disorders at ages 5-7 years: results from the Copenhagen Child Cohort CCC2000. J Child Psychol Psychiatry 55:1328-1335. CrossRef Medline

Elliott CD (2007) Differential ability scales-II (DAS-II). San Antonio, TX: Harcourt Assessment.

Fatemi SH, Halt AR, Realmuto G, Earle J, Kist DA, Thuras P, Merz A (2002) Purkinje cell size is reduced in cerebellum of patients with autism. Cell Mol Neurobiol 22:171-175. CrossRef Medline

Fatemi SH, Aldinger KA, Ashwood P, Bauman ML, Blaha CD, Blatt GJ, Chauhan A, Chauhan V, Dager SR, Dickson PE, Estes AM, Goldowitz D, Heck DH, Kemper TL, King BH, Martin LA, Millen KJ, Mittleman G, Mosconi MW, Persico AM, Sweeney JA, Webb SJ, Welsh JP (2012) Consensus paper: pathological role of the cerebellum in autism. Cerebellum 11:777807. CrossRef Medline

Fellows SJ, Ernst J, Schwarz M, Töpper R, Noth J (2001) Precision grip deficits in cerebellar disorders in man. Clin Neurophysiol 112:1793-1802. CrossRef Medline

Gallese V, Rochat M, Cossu G, Sinigaglia C (2009) Motor cognition and its role in the phylogeny and ontogeny of action understanding. Dev Psychol 45:103-113. CrossRef Medline

Gallese V, Rochat MJ, Berchio C (2013) The mirror mechanism and its potential role in autism spectrum disorder. Dev Med Child Neurol 55:15-22. CrossRef Medline

Gepner B, Mestre D (2002b) Rapid visual-motion integration deficit in autism. Trends Cogn Sci 6:455. CrossRef Medline

Gepner B, Mestre DR (2002a) Brief report: postural reactivity to fast visual motion differentiates autistic from children with Asperger syndrome. J Autism Dev Disord 32:231-238. CrossRef Medline

Gernsbacher MA, Sauer EA, Geye HM, Schweigert EK, Hill Goldsmith H (2008) Infant and toddler oral- and manual-motor skills predict later speech fluency in autism. J Child Psychol Psychiatry 49:43-50. CrossRef Medline

Ghez C, Hening W, Gordon J (1991) Organization of voluntary movement. Curr Opin Neurobiol 1:664-671. CrossRef Medline

Gidley Larson JC, Bastian AJ, Donchin O, Shadmehr R, Mostofsky SH (2008) Acquisition of internal models of motor tasks in children with autism. Brain 131:2894-2903. CrossRef Medline

Glazebrook CM, Elliott D, Lyons J (2006) A kinematic analysis of how young adults with and without autism plan and control goal-directed movements. Motor Control 10:244-264. Medline

Glazebrook C, Gonzalez D, Hansen S, Elliott D (2009) The role of vision for online control of manual aiming movements in persons with autism spectrum disorders. Autism 13:411-433. CrossRef Medline

Gowen E, Miall RC (2005) Behavioural aspects of cerebellar function in adults with Asperger syndrome. Cerebellum 4:279-289. CrossRef Medline

Green G, Brennan LC, Fein D (2002) Intensive behavioral treatment for a toddler at high risk for autism. Behav Modif 26:69-102. CrossRef Medline

Haswell CC, Izawa J, Dowell LR, Mostofsky SH, Shadmehr R (2009) Representation of internal models of action in the autistic brain. Nat Neurosci 12:970-972. CrossRef Medline

Hernandez LM, Rudie JD, Green SA, Bookheimer S, Dapretto M (2015) Neural signatures of autism spectrum disorders: insights into brain network dynamics. Neuropsychopharmacology 40:171-189. CrossRef Medline

Hu X, Newell KM (2010) Adaptation to selective visual scaling of short time scale processes in isometric force. Neurosci Lett 469:131-134. CrossRef Medline

Iacoboni M, Dapretto M (2006) The mirror neuron system and the consequences of its dysfunction. Nat Rev Neurosci 7:942-951. CrossRef Medline
Izawa J, Pekny SE, Marko MK, Haswell CC, Shadmehr R, Mostofsky SH (2012) Motor learning relies on integrated sensory inputs in ADHD, but over-selectively on proprioception in autism spectrum conditions. Autism Res 5:124-136. CrossRef Medline

Jeong JW, Tiwari VN, Behen ME, Chugani HT, Chugani DC (2014) In vivo detection of reduced Purkinje cell fibers with diffusion MRI tractography in children with autistic spectrum disorders. Front Hum Neurosci 8:110. CrossRef Medline

Johnson BP, Rinehart NJ, White O, Millist L, Fielding J (2013) Saccade adaptation in autism and Asperger's disorder. Neuroscience 243:76-87. CrossRef Medline

Kawato M, Furukawa K, Suzuki R (1987) A hierarchical neural-network model for control and learning of voluntary movement. Biol Cybern 57: 169-185. CrossRef Medline

Landa R, Garrett-Mayer E (2006) Development in infants with autism spectrum disorders: a prospective study. J Child Psychol Psychiatry 47:629_ 638. CrossRef Medline

Landa RJ, Gross AL, Stuart EA, Faherty A (2013) Developmental trajectories in children with and without autism spectrum disorders: the first 3 years. Child Dev 84:429-442. CrossRef Medline

LeBarton ES, Iverson JM (2013) Fine motor skill predicts expressive language in infant siblings of children with autism. Dev Sci 16:815-827. CrossRef Medline

Lord C, Rutter M, Le Couteur A (1994) Autism diagnostic interview-revised: a revised version of a diagnostic interview for caregivers of individuals with possible pervasive developmental disorders. J Autism Dev Disord 24:659-685. CrossRef Medline

Lord C, Risi S, Lambrecht L, Cook EH Jr, Leventhal BL, DiLavore PC, Pickles A, Rutter M (2000) The Autism Diagnostic Observation Schedule-Generic: a standard measure of social and communication deficits associated with the spectrum of autism. J Autism Dev Disord 30:205-223. CrossRef Medline

Miall RC, Weir DJ, Stein JF (1985) Visuomotor tracking with delayed visual feedback. Neuroscience 16:511-520. CrossRef Medline

Minshew NJ, Luna B, Sweeney JA (1999) Oculomotor evidence for neocortical systems but not cerebellar dysfunction in autism. Neurology 52:917922. CrossRef Medline

Molinari M, Filippini V, Leggio MG (2002) Neuronal plasticity of interrelated cerebellar and cortical networks. Neuroscience 111:863-870. CrossRef Medline

Mosconi MW, Kay M, D’Cruz AM, Guter S, Kapur K, Macmillan C, Stanford LD, Sweeney JA (2010) Neurobehavioral abnormalities in first-degree relatives of individuals with autism. Arch Gen Psychiatry 67:830-840. CrossRef Medline

Mosconi MW, Luna B, Kay-Stacey M, Nowinski CV, Rubin LH, Scudder C Minshew N, Sweeney JA (2013) Saccade adaptation abnormalities implicate dysfunction of cerebellar-dependent learning mechanisms in autism spectrum disorders (ASD). PLoS One 8:e63709. CrossRef Medline

Mostofsky SH, Bunoski R, Morton SM, Goldberg MC, Bastian AJ (2004) Children with autism adapt normally during a catching task requiring the cerebellum. Neurocase 10:60-64. CrossRef Medline

Mostofsky SH, Powell SK, Simmonds DJ, Goldberg MC, Caffo B, Pekar JJ (2009) Decreased connectivity and cerebellar activity in autism during motor task performance. Brain 132:2413-2425. CrossRef Medline

Müller RA, Cauich C, Rubio MA, Mizuno A, Courchesne E (2004) Abnormal activity patterns in premotor cortex during sequence learning in autistic patients. Biol Psychiatry 56:323-332. CrossRef Medline

Nickel LR, Thatcher AR, Keller F, Wozniak RH, Iverson JM (2013) Posture development in infants at heightened vs. low risk for autism spectrum disorders. Infancy 18:639-661. Medline

Pincus SM, Goldberger AL (1994) Physiological time-series analysis: what does regularity quantify? Am J Physiol 266:H1643-H1656. Medline

Poon C, Coombes SA, Corcos DM, Christou EA, Vaillancourt DE (2013) Transient shifts in frontal and parietal circuits scale with enhanced visual feedback and changes in force variability and error. J Neurophysiol 109: 2205-2215. CrossRef Medline

Reilly JL, Lencer R, Bishop JR, Keedy S, Sweeney JA (2008) Pharmacological treatment effects on eye movement control. Brain Cogn 68:415-435. CrossRef Medline

Robichaud JA, Pfann KD, Vaillancourt DE, Comella CL, Corcos DM (2005) Force control and disease severity in Parkinson's disease. Move Disord 20:441-450. CrossRef Medline

Rost K, Nowak DA, Timmann D, Hermsdörfer J (2005) Preserved and im- 
paired aspects of predictive grip force control in cerebellar patients. Clin Neurophysiol 116:1405-1414. CrossRef Medline

Rutter M, Bailey A, Lord C (2003) Social communication questionnaire (SCQ). Los Angeles: Western Psychological Services.

Schmitt LM, Cook EH, Sweeney JA, Mosconi MW (2014) Saccadic eye movement abnormalities in Autism Spectrum Disorder indicate both cerebellar and brainstorm dysfunctions. Mol Autism 5:47. CrossRef Medline

Shevelkin AV, Ihenatu C, Pletnikov MV (2014) Pre-clinical models of neurodevelopmental disorders: focus on the cerebellum. Rev Neurosci 25: 177-194. CrossRef Medline

Shukla DK, Keehn B, Lincoln AJ, Müller RA (2010) White matter compromise of callosal and subcortical fiber tracts in children with autism spectrum disorder: a diffusion tensor imaging study. J Am Acad Child Adolesc Psychiatry 49:1269-1278, 1278.e1-2. CrossRef Medline

Slifkin AB, Newell KM (1999) Noise, information transmission, and force variability. J Exp Psychol Hum Percept Perform 25:837-851. CrossRef Medline

Slifkin AB, Vaillancourt DE, Newell KM (2000) Intermittency in the control of continuous force production. J Neurophysiol 84:1708-1718. Medline

Sosnoff JJ, Newell KM (2005) Intermittent visual information and the multiple time scales of visual motor control of continuous isometric force production. Percept Psychophys 67:335-344. CrossRef Medline

Sparrow S, Cicchetti D, Balla D (2005) Vineland adaptive behavior scales: (Vineland II), survey interview form/caregiver rating form. Livonia, MN: Pearson Assessments.

Spraker MB, Corcos DM, Kurani AS, Prodoehl J, Swinnen SP, Vaillancourt DE (2012) Specific cerebellar regions are related to force amplitude and rate of force development. Neuroimage 59:1647-1656. CrossRef Medline

Stanfield AC, McIntosh AM, Spencer MD, Philip R, Gaur S, Lawrie SM (2008) Towards a neuroanatomy of autism: a systematic review and meta-analysis of structural magnetic resonance imaging studies. Eur Psychiatry 23:289-299. CrossRef Medline

Stein JF (1986) Role of the cerebellum in the visual guidance of movement. Nature 323:217-221. CrossRef Medline

Stein JF, Glickstein M (1992) Role of the cerebellum in visual guidance of movement. Physiol Rev 72:967-1017. Medline

Stoodley CJ (2014) Distinct regions of the cerebellum show gray matter decreases in autism, ADHD, and developmental dyslexia. Front Syst Neurosci 8:92. Medline

Stoodley CJ, Schmahmann JD (2009) Functional topography in the human cerebellum: a meta-analysis of neuroimaging studies. Neuroimage 44: 489-501. CrossRef Medline

Sutera S, Pandey J, Esser EL, Rosenthal MA, Wilson LB, Barton M, Green J, Hodgson S, Robins DL, Dumont-Mathieu T, Fein D (2007) Predictors of optimal outcome in toddlers diagnosed with autism spectrum disorders. J Autism Dev Disord 37:98-107. CrossRef Medline

Suzuki K, Sugihara G, Ouchi Y, Nakamura K, Futatsubashi M, Takebayashi K, Yoshihara Y, Omata K, Matsumoto K, Tsuchiya KJ, Iwata Y, Tsujii M,
Sugiyama T, Mori N (2013) Microglial activation in young adults with autism spectrum disorder. JAMA Psychiatry 70:49-58. CrossRef Medline

Takarae Y, Minshew NJ, Luna B, Sweeney JA (2004) Oculomotor abnormalities parallel cerebellar histopathology in autism. J Neurol Neurosurg Psychiatry 75:1359-1361. CrossRef Medline

Takarae Y, Minshew NJ, Luna B, Sweeney JA (2007) Atypical involvement of frontostriatal systems during sensorimotor control in autism. Psychiatry Res 156:117-127. CrossRef Medline

Teitelbaum P (2003) A proposed primate animal model of autism. Eur Child Adolesc Psychiatry 12:48-49. CrossRef Medline

Teitelbaum P, Teitelbaum O, Nye J, Fryman J, Maurer RG (1998) Movement analysis in infancy may be useful for early diagnosis of autism. Proc Natl Acad Sci U S A 95:13982-13987. CrossRef Medline

Torres EB, Brincker M, Isenhower RW, Yanovich P, Stigler KA, Nurnberger JI, Metaxas DN, José JV (2013) Autism: the micro-movement perspective. Front Integr Neurosci 7:32. CrossRef Medline

Vaillancourt DE, Newell KM (2000) Amplitude changes in the 8-12, 20-25, and $40 \mathrm{~Hz}$ oscillations in finger tremor. Clin Neurophysiol 111:17921801. CrossRef Medline

Vaillancourt DE, Slifkin AB, Newell KM (2001) Regularity of force tremor in Parkinson's disease. Clin Neurophysiol 112:1594-1603. CrossRef Medline

Vaillancourt DE, Thulborn KR, Corcos DM (2003) Neural basis for the processes that underlie visually guided and internally guided force control in humans. J Neurophysiol 90:3330-3340. CrossRef Medline

Vaillancourt DE, Haibach PS, Newell KM (2006a) Visual angle is the critical variable mediating gain-related effects in manual control. Exp Brain Res 173:742-750. CrossRef Medline

Vaillancourt DE, Mayka MA, Corcos DM (2006b) Intermittent visuomotor processing in the human cerebellum, parietal cortex, and premotor cortex. J Neurophysiol 95:922-931. Medline

Vilis T, Hore J (1980) Central neural mechanisms contributing to cerebellar tremor produced by limb perturbations. J Neurophysiol 43:279-291. Medline

Wechsler D (2011) Wechsler abbreviated scale of intelligence- second edition (WASI-II). San Antonio, TX: Pearson Education.

Williams JH, Whiten A, Waiter GD, Pechey S, Perrett DI (2007) Cortical and subcortical mechanisms at the core of imitation. Soc Neurosci 2:66-78. CrossRef Medline

Wolpert DM, Miall RC (1996) Forward models for physiological motor control. Neural Netw 9:1265-1279. CrossRef Medline

Yip J, Soghomonian JJ, Blatt GJ (2007) Decreased GAD67 mRNA levels in cerebellar Purkinje cells in autism: pathophysiological implications. Acta Neuropathologica 113:559-568. CrossRef Medline

Yip J, Soghomonian JJ, Blatt GJ (2008) Increased GAD67 mRNA expression in cerebellar interneurons in autism: implications for Purkinje cell dysfunction. J Neurosci Res 86:525-530. CrossRef Medline

Young RP, Zelaznik HN (1992) The visual control of aimed hand movements to stationary and moving targets. Acta Psychologica 79:59-78. CrossRef Medline 